\title{
Role of phytochemicals as potential radioprotectants
}

\author{
Sarin A. Chavhan ${ }^{1 *}$, Ravindra L. Bakal2 ${ }^{2}$, Rahul D. Jawarkar², Roshani P. Gandhi ${ }^{3}$, Mayuri P. Chandak ${ }^{4}$ and \\ Israa Lewaa ${ }^{5}$
}

\begin{abstract}
Background: Ionizing radiations causes harm to living organisms and the rapid technological progress has increased human exposure to ionizing radiations enormously. lonizing radiations come in contact with exposure from space radiations, nuclear war, and radiotherapy for cancer-like disease.

Main body of the abstract: There is a need for human beings against these effects of ionizing radiation due to lack of safe and effective radiation available so far, and the traditional medicines used from ancient times of different disease and protection against radiation. A systematic in vivo and in vitro study may use to identify a new lead compound as a radiation shielding agent. The radioprotective properties of plant and herbal extracts, as well as their radioprotective doses, are highlighted in this article. The outcomes of the in vitro and in vivo studies indicate that several botanicals such as Gingko biloba, Centella asiatica, Ocimum sanctum, Panax ginseng, Emblica officinalis, Phyllanthus amarus, Piper longum, Tinospora cordifoila, Mentha arvensis, Mentha piperita, Syzygium cumini, Zingiber officinale, Ageratum conyzoides, Aegle marmelos and Piper betle protect against radiation-induced lethality, lipid peroxidation, and DNA damage.
\end{abstract}

Short conclusion: The fractionation-guided evaluation may help to develop new radioprotectors for targeted activities.

Keywords: Radioprotection, Antioxidant, Cancer, Radiation therapy, Aegle marmelos

\section{Background}

Apart from medical and therapeutic purposes, the use of various types of radiation has increased dramatically in several areas of human life in recent decades, including agriculture, food processing and preservation, industry, nuclear power generation, aviation, space, electronics, communications, and warfare. As a result, while the greatest accomplishments in medicine, science, and technology help mankind live a better life (Hanumakumar et al. 2018), humans and other living species are increasingly exposed to various types of radiation, whether knowingly or unknowingly.

\footnotetext{
${ }^{*}$ Correspondence: sarinchavhan21@gmail.com

1 Department of Pharmacognosy, IBSS's Dr. Rajendra Gode Institute

of Pharmacy, Amravati, Maharashtra 444602, India

Full list of author information is available at the end of the article
}

The global burden of cancer is still increase and radiation treatment is an unavoidable option in the majority of cancer treatments in one stage or other (Ferlay et al. 2010). Radiotherapy inevitably involves exposure to normal tissues apart from targeting cancerous tissues. Radioprotection is an area of great interest due to its wide applications in planned radiotherapy as well as unplanned radiation exposure.

Various natural and synthetic compounds such as antioxidants, cytoprotective agents, immunomodulators, anti-inflammatory molecules, hematopoietic agents, vitamins, and DNA binding molecules have been evaluated extensively for their radio-protective potentials in both in vitro and in vivo models (Bala and Goel 2004; Liu et al. 2015; Maria et al. 2017; Molkentine et al. 2019). Random clinical trials on antioxidants, vitamins to prevent acute adverse effects of radiation indicate that the use of high 
doses of antioxidants as adjuvant therapy might compromise radiation treatment efficacy (Jena et al. 2010). As a result, there is no ideal synthetic radioprotector existing that fulfills all the requirements, such, no cumulative or irreversible toxicity, efficient long-term protection, stability for several years without reducing shelflife, and ease of administration. (Obrador et al. 2020).

Considering, the drawbacks associated with the currently available radioprotectors, plant-based radioprotectants are of great interest because plant-based formulations are used by $70 \%$ of people in the population for to treat a variety of minor to major ailments.

Plants are rich sources of polyphenols which include anthocyanins, flavonoids, stilbenes, tannins, lignins, etc. (Jagetia 2007a). Cells and tissues are equipped with endogenous enzymes e.g. superoxide dismutase (SOD), glutathione peroxidise (GPx), catalase, reduced glutathione (GSH), glutathione $S$ transferase (GST) capable of neutralising free-radical induced cellular damage (Parihar et al.2007). These ionizing radiations damage cells, tissue organs by triggering a chain of molecular events within nanoseconds. i.e. DNA fragmentation resulting in the disruption of living cell or cell death.
Ionizing radiation mainly ceases the "S phase" of mitosis of dividing cell (Hall and Giaccia 2006). They also promote the release of inflammatory cytokines including interleukin 1 (IL-1), and tumor necrosis factor á (TNF a) which act within the irradiated tissue as well as enter systemic circulation experiences cell killings (Brown and Wilson 2004; Rubin et al. 1995).

Once the level of reactive oxygen species increases above tolerable limits, exposure to high dose of ionizing radiation results in damage to the haematopoietic, gastrointestinal and central nervous systems depending on radiation dose (Hosseinimehr et al. 2006). Sepsis, opportunistic infections, neutropenia, and enhanced bacterial colonisation through the diseased gastrointestinal mucosa are the leading causes of death in the early stages of radiation-induced hematopoietic syndrome, due to reduced neutrophils and increased entry of bacteria across the denuded gastrointestinal mucosa. The situation is aggravate by thrombocytopenia and defects in the adaptive immune system (Dainiak 2002). The gastrointestinal barrier is damaged and high amounts of water and electrolytes are lost from the body, resulting in dehydration and bacteraemia (Hosseinimehr 2007) as given in Fig. 1.

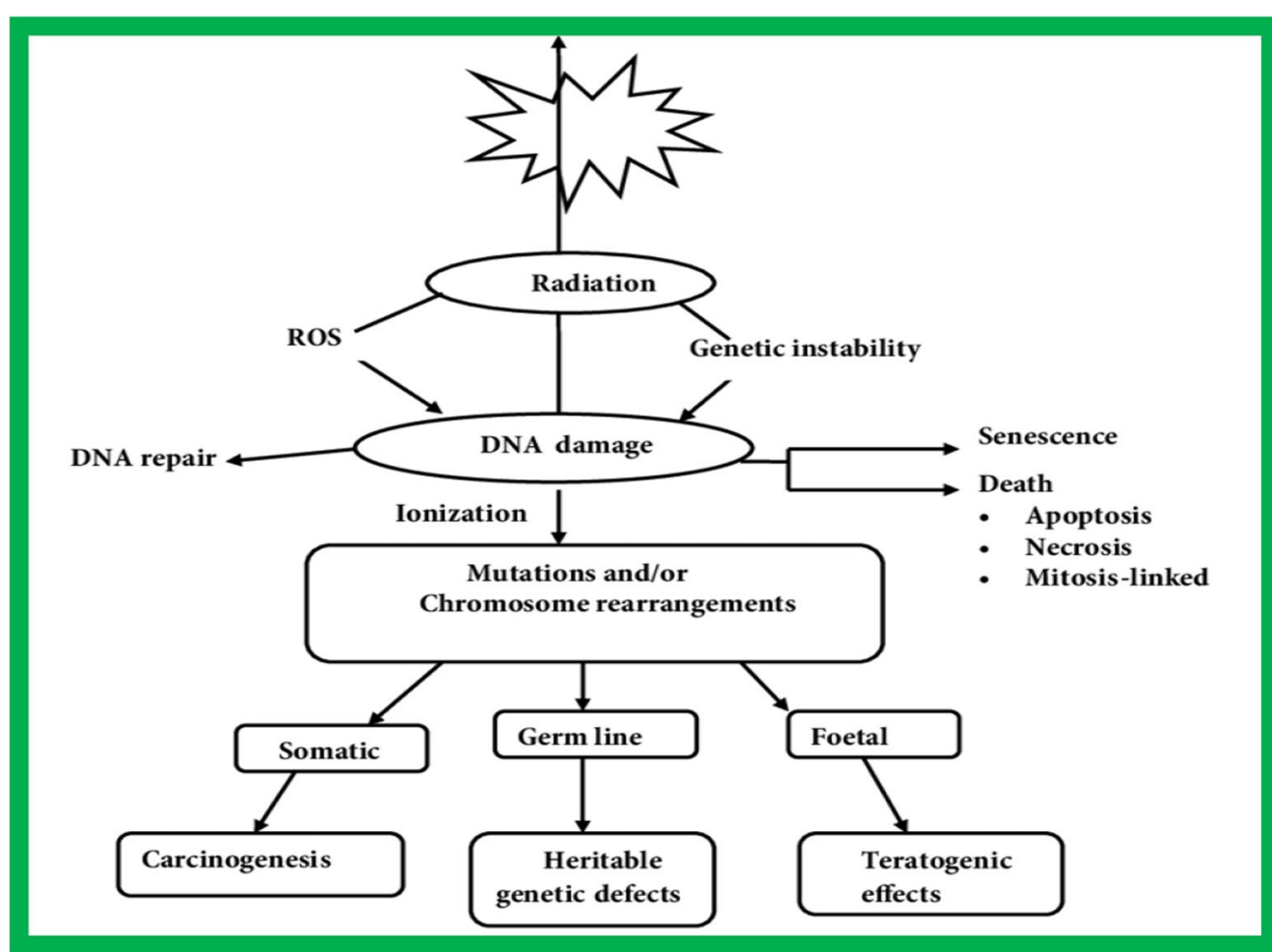

Fig. 1 Effect of radiation on the human body 


\section{Chemical compounds as radioprotectants}

The efficacy of any radioprotector is expressed in terms of dose modifying factor (DMF) or dose reduction factor (DRF). DRF is evaluated by plotting the percentage survival at the end of 30 days against different doses of radiation (Patt et al. 1949).

DMF Radiation LD50 in the presence of the protector DRF Radiation LD50 in the absence of protector

where LD50 is the lethal dose of radiation causing $50 \%$ of death in animals.

\section{Main text}

\section{Naturally occurring radioprotectors}

Amifostine is currently the only chemical drug approved by the FDA for protecting against the toxicity of radiotherapy in cancer patients. Similar to thiols, aminothiols, thiadiazoles, and benzothiazoles, the amifostine free radical scavenger is an organic thiol phosphate precursor and chemical radioprotectant. However, the efficacy of such chemical radioprotectors is restricted due to their high toxicity and associated side effects (Mun et al. 2018).

Plant is the best resource as radioprotective because there is a presence of chemical constituents that are responsible for antioxidant action, efficient, economically viable and clinically acceptable for human application. Many plants are rich sources of phytochemicals, flavonoids (quercetin, orientin, myricetin-flavonol, luteolinflavone and (-)-epigallo catechingallate-flavanol, rutin, naringin, etc.), have been reported as potent antioxidants with radioprotective abilities (Benkovic et al. 2008; Lee et al. 2017) mention in Tables 1 and 2.

Polyphenols have an antioxidant activity that is activated by radiation. Polyphenols could up-regulate messenger RNA of antioxidant enzymes such as catalase, GSH transferase, GSHPx, superoxide dismutase (SOD) and hence reducing oxidative stress and repairing RNA damage (Faramarzi et al. 2021).

The plants and herbs may also suppress the activation of protein kinase $\mathrm{C}$, mitogen activated protein kinase, cytochrome P-450, nitric oxide and several other genes that may be responsible for inducing damage after irradiation (Jagetia 2007b) as given in Fig. 2. A variety of plant-derived materials such as polysaccharides, lectins, peptides flavonoids and tannins have been reported to modulate the immune system with potent good immunomodulatory activity.

Given the urgent need for effective and safe medicinal resources and the broad range of circumstances in which radioprotectors are required, future efforts to develop natural radioprotectors remain great important.

\section{Plants and herbs as radioprotectants}

\section{Curcuma longa (Haldi)}

It is a perennial shrub of the Zingiberaceae family that can be found in almost all Indian states, but especially in Bengal, Mumbai, Andhra Pradesh and Tamil Nadu where it is cultivated for commercial reasons. Widespread research in the last decade in cell culture and rodents has shown that curcumin can sensitizes tumors to different chemotherapeutic agents. Likewise, evidence to demonstrates that this agent can sensitize a variety of tumors to $\gamma$-GR including glicoma, neuroblastoma, cervical carcinoma, epidermal carcinoma, prostate cancer, and colon cancer. Earlier research has shown that it down-regulates several growth regulatory pathways and precise genetic targets including genes for nuclear factor kappa-lightchain-enhancer of activated B cells, signal transducer and activator of transcription 3, cyclooxygenase-2, Akt (also known as protein kinase B), anti-apoptotic proteins, growth factor receptors, and multidrug-resistance proteins (Goel and Curcumin 2010) Curcumin been shown to safeguard normal organs against chemotherapy and radiotherapy-induced damage, while also acting as a chemosensitizer and radiosensitizer for malignancies in some cases. So Curcumin plays dual actions of radio protecting non-cancerous normal cells while radio sensitizing tumor cells.

It seems that the protective effects of the curcumin are facilitated through their ability to induce the activation and expression of antioxidant enzymes, directly quench free radicals, and inhibit p300 histone acetyl transferase (HAT) activity. These preclinical studies are designed to lead clinical trials to prove the potential of this age-old golden spice for treating cancer patients and radiation effects (Jagetia 2007b). As indicate, Curcuma longa (as shown in Fig. 3) has a beneficial radioprotective effect against radiation-induced oxidative stress in male rats by alleviating pathological disorders and modulating antioxidant enzymes (Nada et al. 2012).

\section{Ocimum sanctum (Tulsi)}

It is a Lamiaceae family herb that is extensively spread in tropical and mild temperate regions. Ocimum genus contains about 130 species of herbs and shrubs from the tropical regions of Asia (Bailey 1924; Upadhyay et al. 2015). In albino mice, an aqueous-ethanolic extract of $O$. sanctum was reported to have a radioprotective effect against gamma radiation. The optimal dose for protection has been reported to be $50 \mathrm{mg} / \mathrm{kg}$ body weight while the acute LD50 was $6 \mathrm{~g} / \mathrm{kg}$ body weight. Ocimum flavonoid, orientin and FDA-approved amifostine were found to exhibit a similar radioprotection at the doses of $50 \mathrm{mg} / \mathrm{kg}$ body weight and $150 \mathrm{mg} / \mathrm{kg}$ body weight 


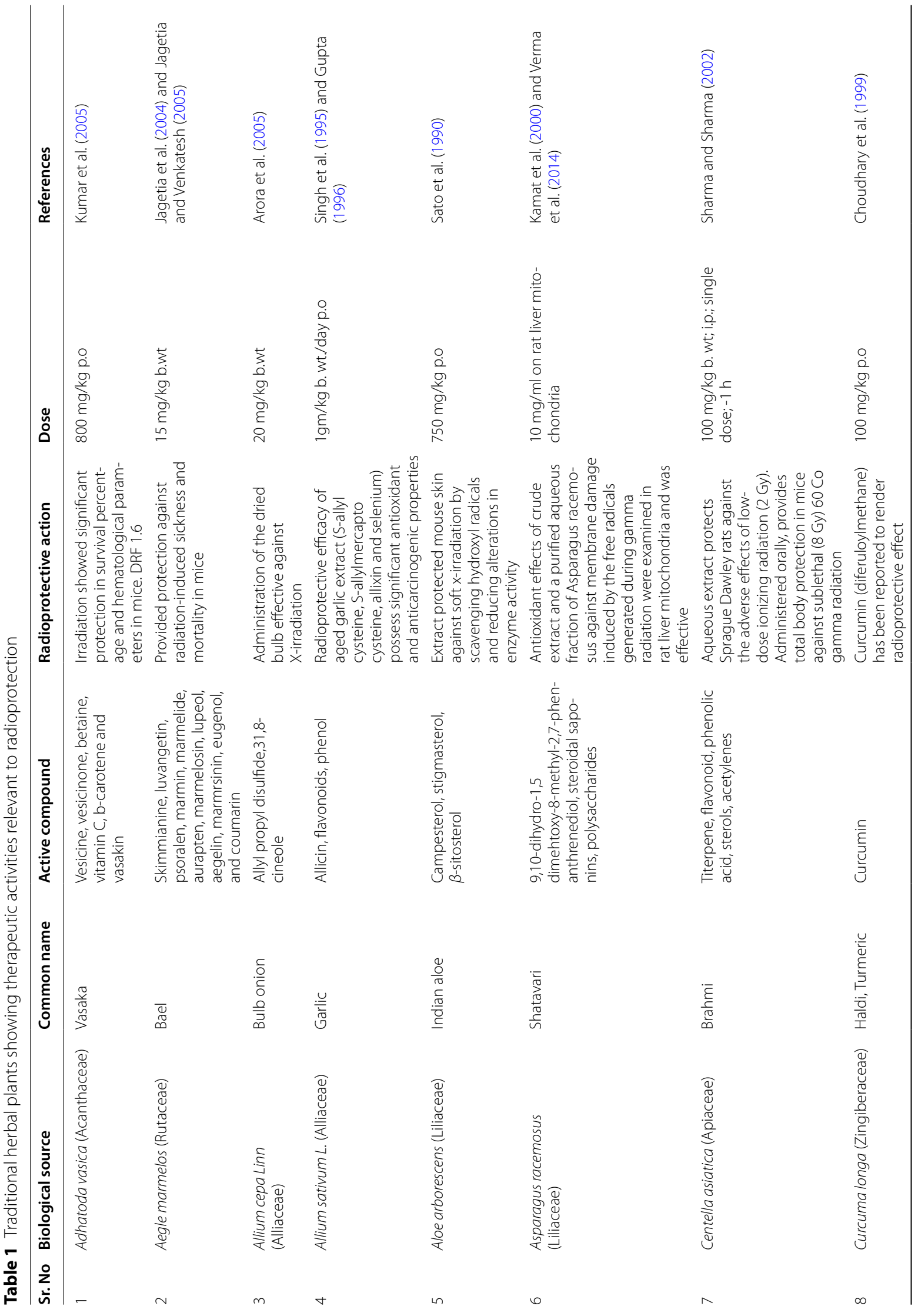




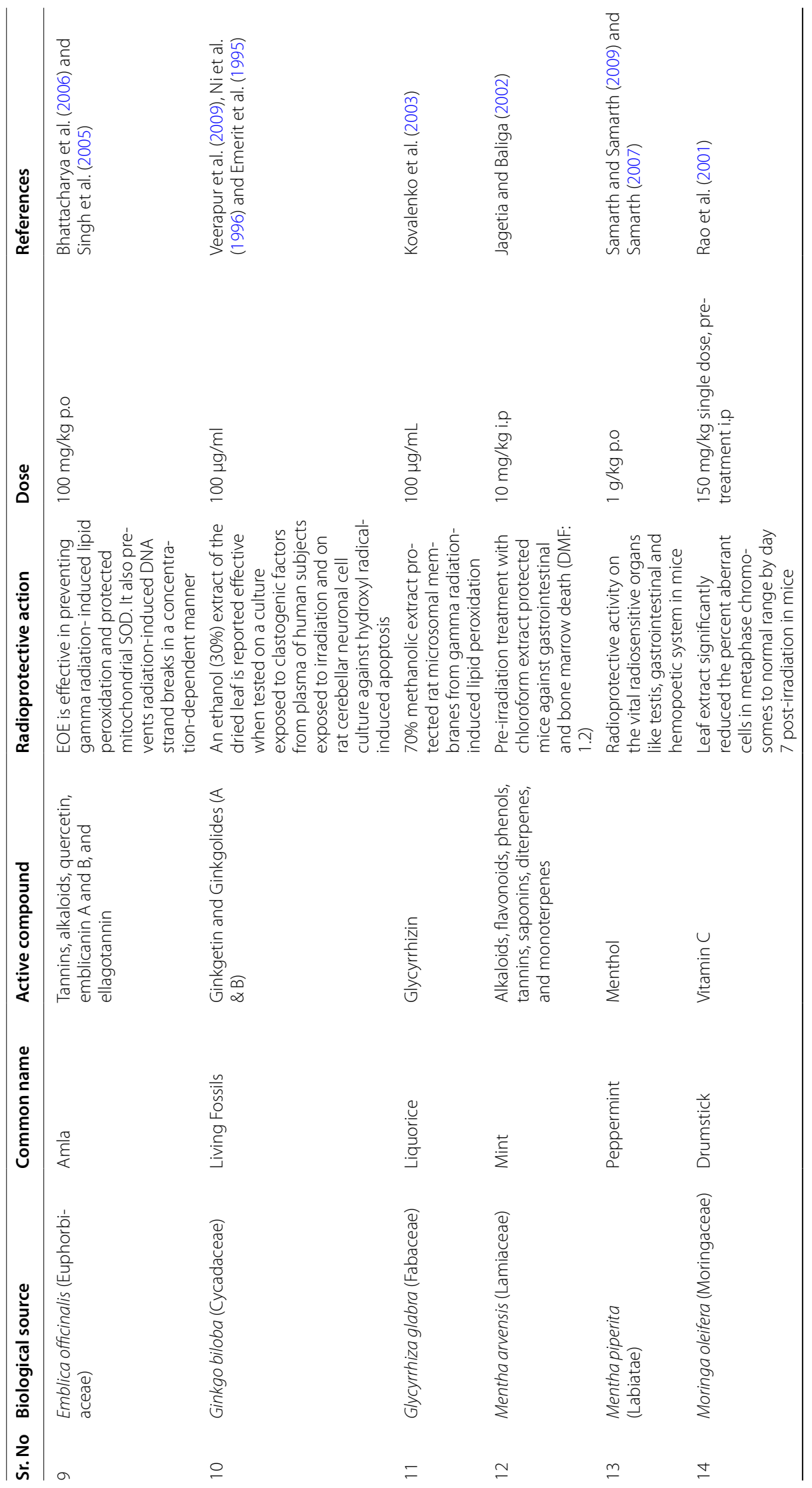




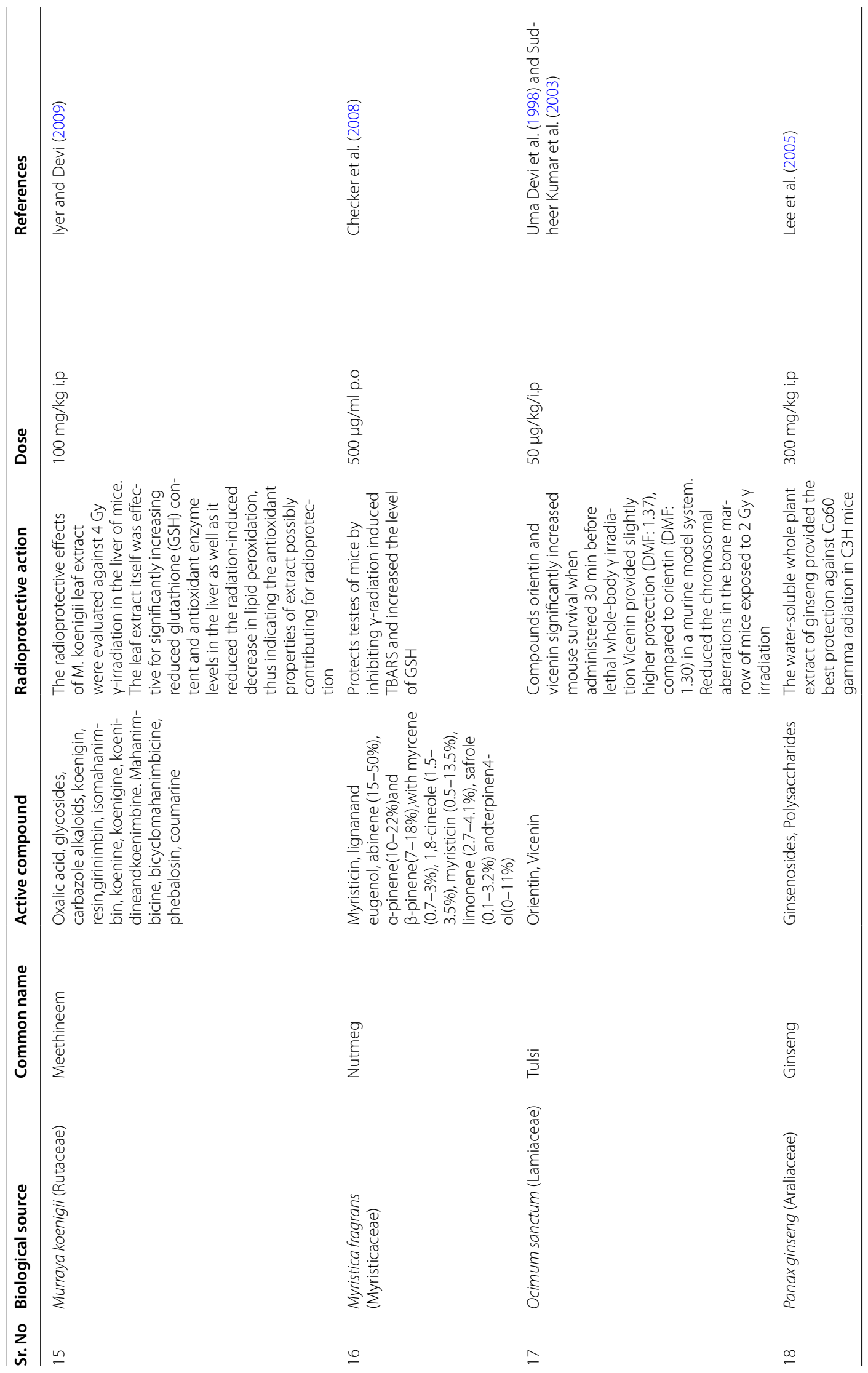




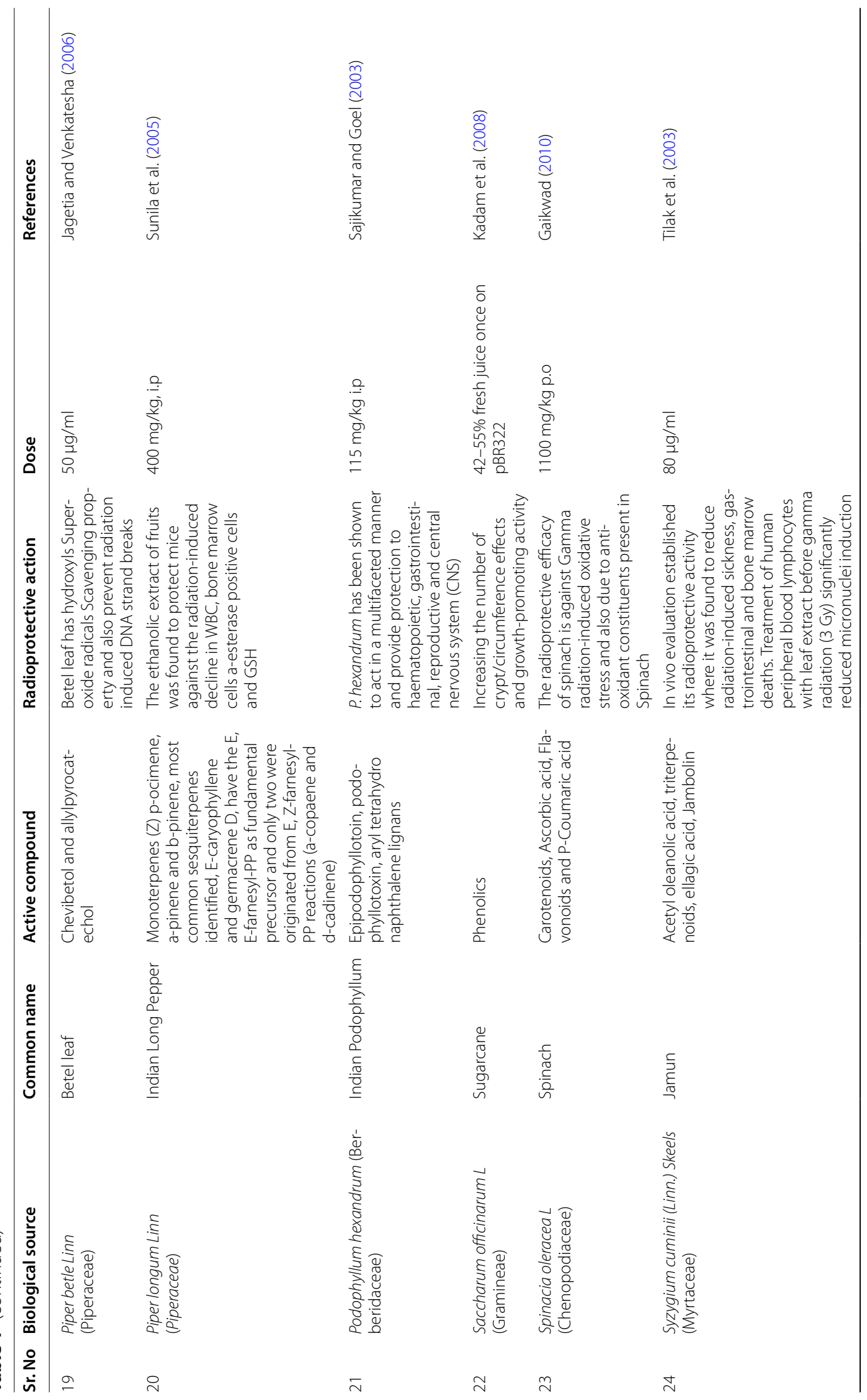




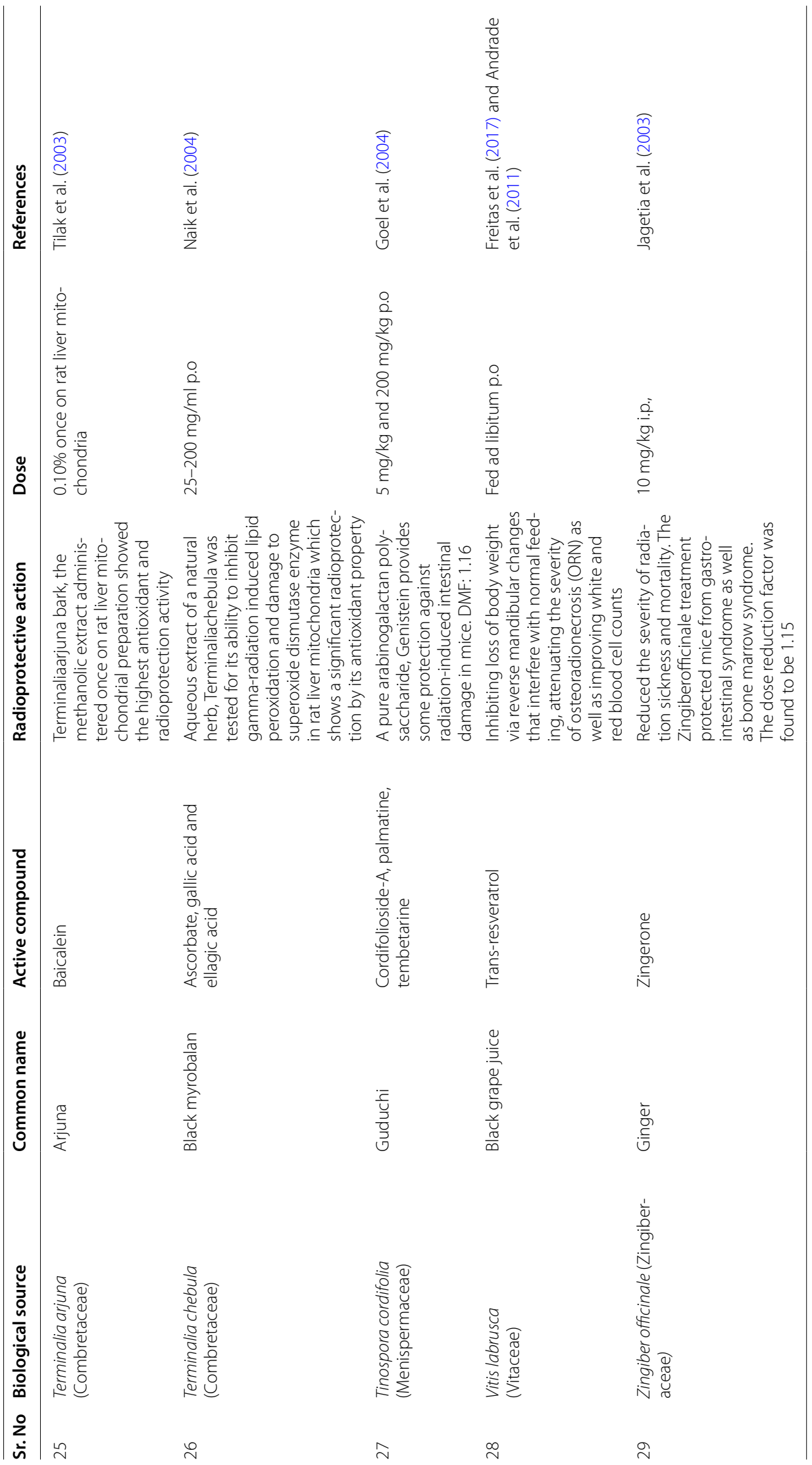


Table 2 Phytochemistry of some radioprotectives

(nasicine

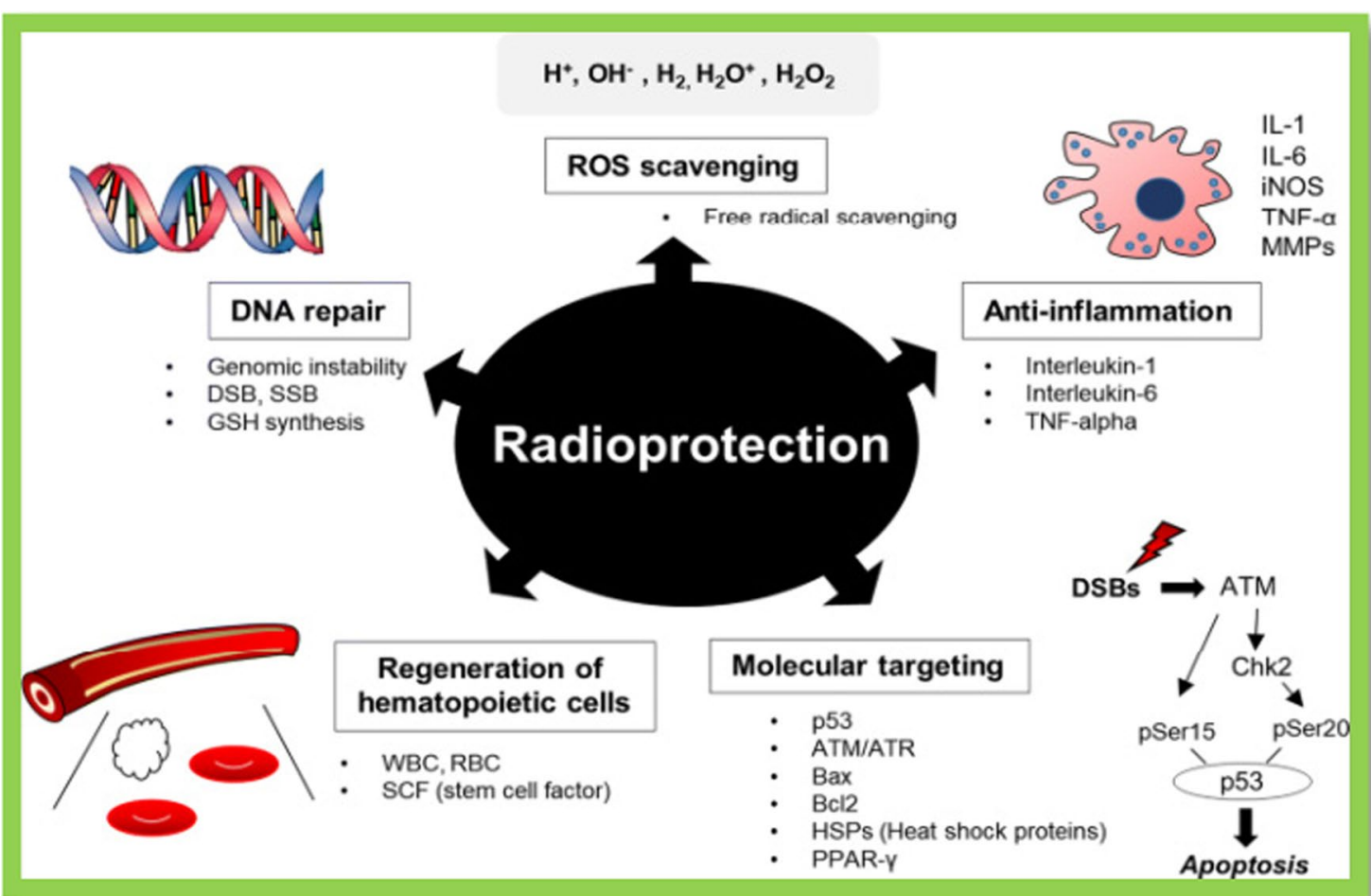

Fig. 2 Pharmacology of natural radioprotectants 


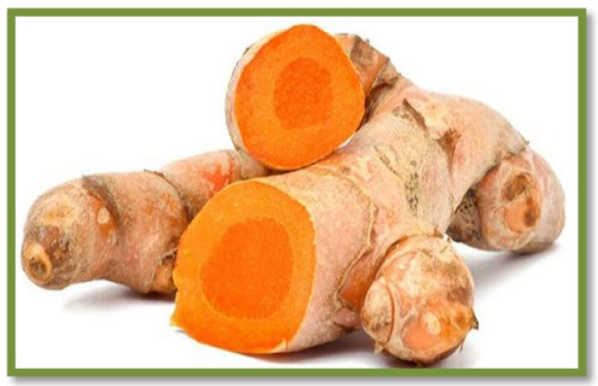

Fig. 3 Curcuma longa

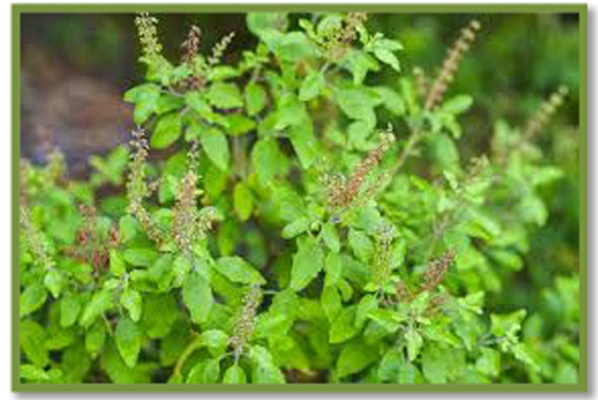

Fig. 4 Ocimum sanctum

respectively, upon irradiation with 2 Gy-gamma radiation whereas vicenin showed lesser activity (Uma Devi et al. 1999). Ocimum has been shown to have anti-melanoma and radioprotective properties in C57BL and Swiss Albino mice. The aqueous extract of Ocimum (as shown in Fig. 4) reduced tumor volume, increase in average body weight, and survival rate of mice. Radiation-induced chromosomal damage was modulated by Ocimum extracts, which caused an increase in reduced GSH level and GST activity. Radical scavenging activity has been demonstrated for both orientin and vicenin, and this appears to be one of the mechanisms of protection by these flavonoids (Baliga et al. 2012).

\section{Zingiber officinale (Ginger)}

It is an herbaceous perennial flowering plant, native to south China, spreading eventually to the Spice Islands and other parts of Asia and subsequently to West Africa. The rhizome of $Z$. officinale (as shown in Fig. 5) commonly known as ginger (Sunthi/Ardraka) has widely been used as a spice and condiment in different societies since antiquity. Numerous preclinical researches have revealed that ginger has chemopreventive and anticancer effects (Baliga et al. 2012). Preclinical studies carried out in the last decade have shown that ginger and its phytochemicals dehydrozingerone an zingerone possess

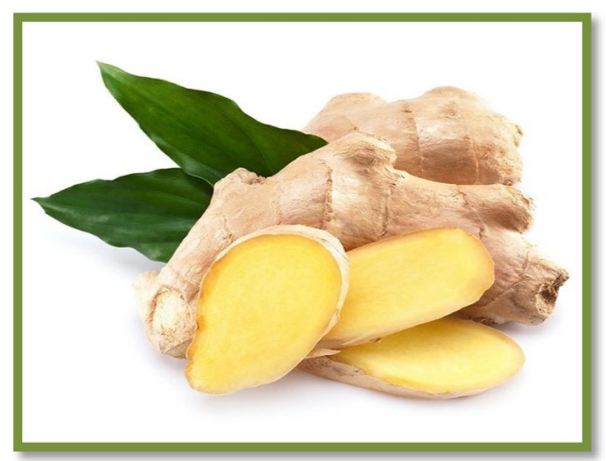

Fig. 5 Zingiber officinale

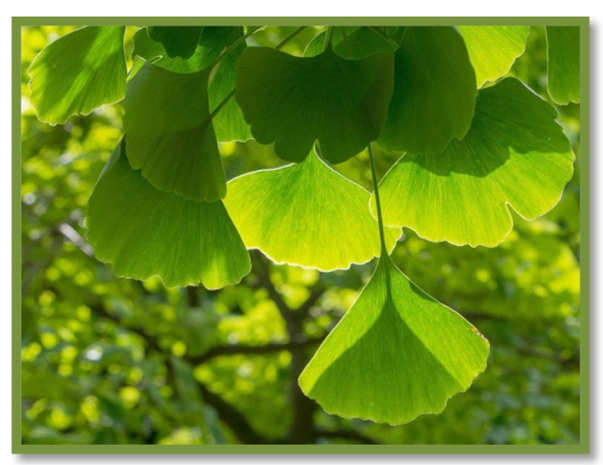

Fig. 6 Ginkgo biloba

radioprotective effects in laboratory animals and cultured cells in-vitro. Mechanistic studies have indicated that free radical scavenging, antioxidant, anti-inflammatory and anti-clastogenic effects may contribute towards the observed protection. Furthermore, research on tumorbearing mice have also shown that zingerone selectively protects the normal tissues against the tumoricidal effects of radiation (Pereira et al. 2011).

\section{Ginkgo biloba (Bramhi)}

Ginkgo biloba (Cycadaceae), a plant native to China, Japan and Korea, has been reported to stimulate endogenous antioxidants such as glutathione and attenuate oxidative stress.

A Ginkgo biloba extract, which is a mixture of flavonoids, heterosides and terpenes with antioxidant properties, has been shown to prevent mitochondrial aging by reducing oxidative damage. Ginkgo biloba (as shown in Fig. 6) extract is also useful in the treatment of cerebral disorders due to aging and hypoxia. Nearly $300 \mathrm{com}-$ pounds are present in Ginkgo biloba including ascorbic acid, $\alpha$-carotene, $\beta$-carotene, flavonoids, coumarins, catechins, ginkgolides, bilobalide, rhamnetin, $\gamma$-tocopherol to 
name a few, many of which individually in isolated form render radioprotective effects.

The extract of Ginkgo biloba protected brain neurons from oxidative stress. G. biloba leaf extract (30\%) at a concentration of $100 \mu \mathrm{g} / \mathrm{mL}$ assayed in rat cerebellar neuronal cell culture, was active on neurons against hydroxyl radical-induced apoptosis (Arora et al. 2005).

\section{Piper betle (Betel Leaf/Pan)}

It is a tropical perennial evergreen plant that flourishes in the shadow belongs from Piparaceae family, native to central and eastern Malaysia and was taken into cultivation throughout Malaysia and tropical Asia. The radioprotective activity of Piper betel (as shown in Fig. 7) ethanolic extract (PE) has been studied using rat liver mitochondria and pBR322 plasmid DNA as two models in vitro systems (Bhattacharya et al. 2005). The extract effectively prevented gamma-ray induced lipid peroxidation as assessed by measuring thiobarbituric acid reactive substrates, lipid hydroperoxide and conjugated diene. Likewise, it prevented radiation-induced DNA strand breaks in a concentration dependent manner. The radioprotective activity of PE because of its hydroxyl and superoxide radical scavenging property along with its lymphoproliferative activity. The presence of phenolic components, which were separated and identified as chevibetol, was principally responsible for PE's radical scavenging activity (Bhattacharya et al. 2005).

\section{Conclusions}

Due to the frequent exposure to ionizing radiation in many aspects of human life in particular areas relating to cancer radiation therapy, food preservation, agriculture, industry and power generation, there is a necessity to develop an effective and nontoxic radioprotector.

Thus, the increased use of nuclear radiation for human welfare requires the search for new, safe and inexpensive radioprotectors not only for workers who

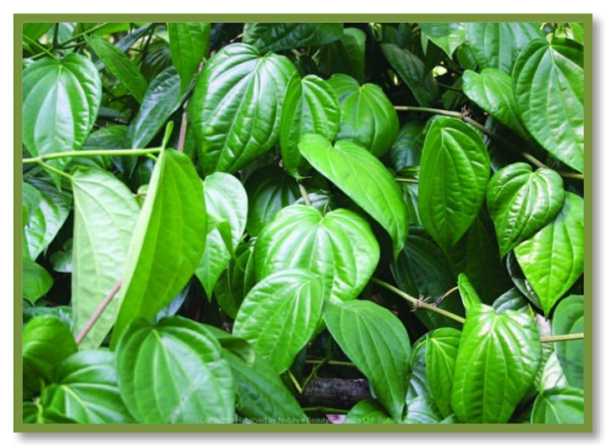

Fig. 7 Piper betel are responsible for testing or working with radiation in laboratories but also for the general public.

We are mention in this review Curcuma longa, Ocimum sanctum, Zingiber officinale, Ginkgo biloba and Piper betle this each plants consist of secondary metabolites like terpenoids, resins, triterpenoids which responsible for radioprotective action. The success of the development of radioprotective agents is increasingly and depended on the understanding of the molecular biology of radiation damage, cellular, tissue, organ responses to irradiation, the effect of co-morbid factors, and differences between tumor and normal cell biology, thus leading to an overall improvement in the efficacy of anticancer treatment. India has a traditional medicinal plant heritage, so it is possible to develop efficient, economically feasible and clinically efficiency and acceptable radioprotectors for human application of these resources. Most of these phytochemicals are used as immunomodulators in case of life-threatening diseases such as HIV-AIDS, corona, cancer, etc.

Thus, the current literature will bring more phytochemicals to develop new research into the radioprotection of suffering humanity and support the treatment of cancer.

\section{Abbreviations}

CNS: Central Nervous System; DMF: Dose Modifying Factor; DRF: Dose Reduction Factor; GPx: Glutathione Peroxidase; GSH: Catalase, Reduced Glutathione; GST: Glutathione STransferase; HAT: Histone Acetyl Transferase; IL-1: Deoxyribonucleic Acid; ORN: Osteoradionecrosis; SOD: Superoxide Dismutase; TNF-a: Tumor Necrosis Factor a

\section{Acknowledgements}

The authors are thankful to Hon. Yogendraji Gode, President of IBSS's Dr. Rajendra Gode Institute of Pharmacy, Amravati and Dr. Ravindra L. Bakal, Principal of Dr. Rajendra Gode Institute of Pharmacy, Amravati for their permission and support for the article.

\section{Authors' contributions}

The Concept was discussed by RJ while SC prepare the writing original draft of the article followed by RB with validation and data analysis, MC contributes with data collection, RG and IL checked the grammar and remove all the plagiarism then RJ Review and edit the article and finally SC done the formal analysis of the article. All the author read and approved the final manuscript.

Funding

Not applicable.

Availability of data and materials

Data is collected from various resources such as Pubmed data base, Google scholar and various research journals.

\section{Declarations}

Ethics approval and consent to participate Not applicable.

Consent for publication

Not applicable. 


\section{Competing interests}

The authors declare that they have no competing financial interests or personal relationships that could have appeared to influence the work reported in this paper

\section{Author details}

${ }^{1}$ Department of Pharmacognosy, IBSS's Dr. Rajendra Gode Institute of Pharmacy, Amravati, Maharashtra 444602, India. ${ }^{2}$ Department of Pharmaceutical Chemistry, IBSS's Dr. Rajendra Gode Institute of Pharmacy, Amravati, India. ${ }^{3}$ Government College of Pharmacy, Amravati 444602, MS, India. ${ }^{4}$ Dr. Rajendra Gode College of Pharmacy, Malkapur, MS 443101, India. ${ }^{5}$ Department of Business Administration, Faculty of Business Administration, Economics and Political Science, British University in Egypt, Cairo, Egypt.

\section{Received: 22 November 2021 Accepted: 16 February 2022} Published online: 03 March 2022

\section{References}

Andrade ER, Cruz IB, Andrade W, Piccoli JC, González-Gallego J, Barrio JP, González P (2011) Evaluation of the potential protective effects of ad libitum black grape juice against liver oxidative damage in whole-body acute X-irradiated rats. Food Chem Toxicol 49(4):1026-1032

Arora R, Gupta D, Chawla R, Sagar R, Sharma A, Kumar R, Prasad J, Singh S, Samanta N, Sharma RK (2005) Radioprotection by plant products: present status and future prospects. Phytother Res 19(1):1-22

Bailey LH (1924) Manual of cultivated plants. Macmillan Co., New York, pp $101-103$

Bala M, Goel HC (2004) Radioprotective effect of podophyllotoxin in Saccharomyces cerevisiae. J Environ Pathol Toxicol Oncol 23(2):139-144

Baliga MS, Haniadka R, Pereira MM, Thilakchand KR, Rao S, Arora R (2012) Radioprotective effects of Zingiber officinale Roscoe (ginger): past, present and future. Food Funct 3(7):714-723

Benkovic V, Knezevic AH, Dikic D, Lisicic D, Orsolic N, Basic I, Kosalec I, Kopjar N (2008) Radioprotective effects of propolis and quercetin in gammairradiated mice evaluated by the alkaline comet assay. Phytomedicine 15(10):851-858

Bhattacharya S, Subramanian M, Roychowdhury S, Bauri AK, Kamat JP, Chattopadhyay S, Bandyopadhyay SK (2005) Radioprotective property of the ethanolic extract of Piper betel Leaf. J Radiat Res 46(2):165-171

Bhattacharya S, Subramanian M, Kamat JP, Bandyopadhyay SK, Chattopadhyay S (2006) Radioprotective property of Emblica officinalis fruit ethanol extract. Pharm Biol 44(9):682-690

Brown JM, Wilson WR (2004) Exploiting tumour hypoxia in cancer treatment. Nat Rev Cancer 4:437-447

Checker R, Chatterjee S, Sharma D, Gupta S, Variyar P, Sharma A, Poduval TB (2008) Immunomodulatory and radioprotective effects of lignans derived from fresh nutmeg mace (Myristica fragrans) in mammalian splenocytes. Int Immunopharmacol 8(5):661-669

Choudhary D, Chandra D, Kale RK (1999) Modulation of radioresponse of glyoxalase system by curcumin. J Ethnopharmacol 64(1):1-7

Dainiak N (2002) Hematologic consequences of exposure to ionizing radiation. Exp Hematol 30(6):513-528

Emerit I, Arutyunyan R, Oganesian N, Levy A, Cernjavsky L, Sarkisian T, Pogossian A, Asrian K (1995) Radiation-induced clastogenic factors: anticlastogenic effect of Ginkgo biloba extract. Free Radic Biol Med 18(6):985-991

Faramarzi S, Piccolella S, Manti L, Pacifico S (2021) Could polyphenols really be a good radioprotective strategy? Molecules 26(16):4969. https://doi.org/ 10.3390/molecules26164969.PMID:34443561;PMCID:PMC8398122

Ferlay J, Shin HR, Bray F, Forman D, Mathers C, Parkin DM (2010) Estimates of worldwide burden of cancer in 2008: GLOBOCAN 2008. Int J Cancer 127(12):2893-2917

Freitas RB, González P, Martins NM, Andrade ER, Cesteros Morante MJ, Conles Picos I, Costilla García S, Bauermann LF, Barrio JP (2017) Ameliorative effect of black grape juice on systemic alterations and mandibular osteoradionecrosis induced by whole brain irradiation in rats. Int J Radiat Biol 93(2):204-213

Gaikwad PS (2010) Spinacia oleracea Linn. A pharmacogenetic and pharmacological overview. Int J Res in Ayurveda and Pharm 1(1):78-84
Goel A, Curcumin ABB (2010) The golden spice from Indian saffron, is a chemosensitizer and radiosensitizer for tumors and chemoprotector and radioprotector for normal organs. Nutr Cancer 62(7):919-930

Goel HC, Prasad J, Singh S, Sagar RK, Agrawala PK, Bala M, Sinha AK, Dogra R (2004) Radioprotective potential of an herbal extract of Tinospora cordifolia. J Radiat Res 45(1):61-68

Gupta NK (1996) Modification of radiation induced changes in murine hepatic lipid profiles by garlic (Allium sativum Linn.) unsaturated oils. Indian J Exp Biol 34(9):851-853

Hall E, Giaccia A (2006) Radiobiology for the radiologist, 6th edn. Lippincott Williams \& Wilkins, Philadelphia

Hanumakumar GE, Balaji M, Karunakaran RS (2018) Enhanced human exposure to radiations, role of phytochemicals as potential radio-protectants: a review. Int J Pharm Sci Res 9(7):2656-2668

Hosseinimehr SJ (2007) Trends in the development of radioprotective agents. Drug Discov Today 12(19-20):794-805

Hosseinimehr SJ, Zakaryaee V, Froughizadeh M (2006) Oral oxymetholone reduces mortality induced by gamma irradiation in mice through stimulation of hematopoietic cells. Mol Cell Biochem 287(1-2):193-199

Iyer D, Devi PU (2009) Radioprotective activity of Murraya koenigii (I.) on cellular antioxidants in swiss albino mice. J Pharm Res 2(3):495-501

Jagetia GC (2007a) Radioprotective potential of plants and herbs against the effects of ionizing radiation. J Clin Biochem Nutr 40(2):74-81

Jagetia GC (2007b) Radioprotection and radiosensitization by curcumin. Adv Exp Med Biol 595:301-320

Jagetia GC, Baliga MS (2002) Influence of the leaf extract of Mentha arvensis Linn. (mint) on the survival of mice exposed to different doses of gamma radiation. Strahlenther Onkol 178(2):91-98

Jagetia GC, Venkatesh P (2005) Radioprotection by oral administration of Aegle marmelos (L.) Correa in vivo. J Environ Pathol Toxicol Oncol 24(4):315-332

Jagetia GC, Venkatesha VA (2006) Treatment of mice with stem bark extract of Aphanamixis polystachya reduces radiation-induced chromosome damage. Int J Radiat Biol 82(3):197-209

Jagetia GC, Baliga MS, Venkatesh P, Ulloor JN (2003) Influence of ginger rhizome (Zingiber officinale Rosc) on survival, glutathione and lipid peroxidation in mice after whole-body exposure to gamma radiation. Radiat Res 160(5):584-592

Jagetia GC, Venkatesh P, Baliga MS (2004) Evaluation of the radioprotective effect of bael leaf (Aegle marmelos) extract in mice. Int J Radiat Biol 80(4):281-290

Jena G, Vikram A, Tripathi DN, Ramarao P (2010) Use of chemoprotectants in chemotherapy and radiation therapy: the challenges of selecting an appropriate agent. Integr Cancer Ther 9(3):253-258

Kadam US, Ghosh SB, De S, Suprasanna P, Devasagayam TPA, Bapat VA (2008) A antioxidant activity in sugarcane juice and its protective role against radiation induced DNA damage. Food Chem 106:1154-1160

Kamat JP, Boloor KK, Devasagayam TP, Venkatachalam SR (2000) Antioxidant properties of Asparagus racemosus against damage induced by gammaradiation in rat liver mitochondria. J Ethnopharmacol 71(3):425-435

Kovalenko PG, Antonjuk VP, Maluita SS (2003) Secondary metabolites production from transformed cells of Glycyrrhiza glabra and Potentil laalba producents of radioprotective compounds. Ukr Biorgan Acta 1:1-17

Kumar A, Ram J, Samarth RM, Kumar M (2005) Modulatory influence of Adhatoda vasica Nees leaf extract against gamma irradiation in Swiss albino mice. Phytomedicine 12(4):285-293

Lee TK, Johnke RM, Allison RR, O'Brien KF, Dobbs LJ Jr (2005) Radioprotective potential of ginseng. Mutagenesis 20(4):237-243

Lee MT, Lin WC, Yu B, Lee TT (2017) Antioxidant capacity of phytochemicals and their potential effects on oxidative status in animals-a review. Asian-Australas J Anim Sci 30(3):299-308

Liu W, Chen Q, Wu S, Xia X, Wu A, Cui F, Gu YP, Zhang X, Cao J (2015) Radioprotector WR-2721 and mitigating peptidoglycan synergistically promote mouse survival through the amelioration of intestinal and bone marrow damage. J Radiat Res 56(2):278-286

Maria OM, Eliopoulos N, Muanza T (2017) Radiation-induced oral mucositis. Front Oncol 7:89

Molkentine JM, Fujimoto TN, Horvath TD, Grossberg AJ, Garcia CJG, Deorukhkar A, de la Cruz BM, Lin D, Samuel ELG, Chan WK, Lorenzi PL, Piwnica-Worms H, Dantzer R, Tour JM, Mason KA, Taniguchi CM (2019) Enteral activation of WR-2721 mediates radioprotection and improved survival from lethal fractionated radiation. Sci Rep 9(1):1949 
Mun Gl, Kim S, Choi E, Kim CS, Lee YS (2018) Pharmacology of natural radioprotectors. Arch Pharm Res 41(11):1033-1050. https://doi.org/10. 1007/s12272-018-1083-6. Erratum in: Arch Pharm Res 42:732-734, 2019; Erratum in: Arch Pharm Res 43(2):272-274, 2020

Nada AS, Hawas AM, Nel-D A, Elnashar MM, AbdElmageed ZY (2012) Radioprotective effect of Curcuma longa extract on $\gamma$-irradiation-induced oxidative stress in rats. Can J Physiol Pharmacol 90(4):415-423

Naik GH, Priyadarsini KI, Naik DB, Gangabhagirathi R, Mohan H (2004) Studies on the aqueous extract of Terminalia chebula as a potent antioxidant and a probable radioprotector. Phytomedicine 11(6):530-538

Ni Y, Zhao B, Hou J, Xin W (1996) Preventive effect of Ginkgo biloba extract on apoptosis in rat cerebellar neuronal cells induced by hydroxyl radicals Neurosci Lett 214(2-3):115-118

Obrador E, Salvador R, Villaescusa JI, Soriano JM, Estrela JM, Montoro A (2020) Radioprotection and radiomitigation: from the bench to clinical practice. Biomedicines 8(11):461

Parihar VK, Dhawan J, Kumar S, Manjula SN, Subramanian G, Unnikrishnan MK, Rao CM (2007) Free radical scavenging and radioprotective activity of dehydrozingerone against whole body gamma irradiation in Swiss albino mice. Chem Biol Interact 170(1):49-58

Patt HM, Tyree EB, Straube RL, Smith DE (1949) Cysteine protection against X irradiation. Science 110(2852):213-214

Pereira MM, Haniadka R, Chacko PP, Palatty PL, Baliga MS (2011) Zingiber officinale Roscoe (ginger) as an adjuvant in cancer treatment: a review. J BUON 16(3):414-424

Rao AV, Devi PU, Kamath R (2001) In vivo radioprotective effect of Moringa oleifera leaves. Indian J Exp Biol 39(9):858-863

Rubin P, Johnston CJ, Williams JP, McDonald S, Finkelstein JN (1995) A perpetual cascade of cytokines postirradiation leads to pulmonary fibrosis. Int J Radiat Oncol Biol Phys 3(1):99-109

Sajikumar S, Goel HC (2003) Podophyllum hexandrum prevents radiationinduced neuronal damage in postnatal rats exposed in utero. Phytother Res 17(7):761-766

Samarth RM (2007) Protection against radiation induced hematopoietic damage in bone marrow of Swiss albino mice by Mentha piperita (Linn). J Radiat Res 48(6):523-528

Samarth RM, Samarth M (2009) Protection against radiation-induced testicular damage in Swiss albino mice by Mentha piperita (Linn.). Basic Clin Pharmacol Toxicol 104(4):329-334

Sato Y, Ohta S, Shinoda M (1990) [Studies on chemical protectors against radiation XXXI. Protection effects of Aloe arborescens on skin injury induced by X-irradiation]. Yakugaku Zasshi 110(11):876-884 (in Japanese)

Sharma J, Sharma R (2002) Radioprotection of Swiss albino mouse by Centella asiatica extract. Phytother Res 16(8):785-786

Singh SP, Abraham SK, Kesavan PC (1995) In vivo radioprotection with garlic extract. Mutat Res 345(3-4):147-153

Singh I, Sharma A, Nunia V, Goyal PK (2005) Radioprotection of swiss albino mice by Emblica officinalis. Phytother Res 19(5):444-446

Sudheer Kumar M, Unnikrishnan MK, Uma Devi P (2003) Effect of 5-aminosalicylic acid on radiation-induced micronuclei in mouse bone marrow. Mutat Res 527(1-2):7-14

Sunila ES, Kuttan G (2005) Protective effect of Piper longum fruit ethanolic extract on radiation induced damages in mice: a preliminary study. Fitoterapia 76(7-8):649-655

Tilak JC, Devasagayam TPA, Adhikari S (2003) Radioprotective and antioxidant properties of Indian medicinal plant, Terminalia arjuna. BARC Newslett 249:169-176

Uma Devi P, Satish Rao BS, Kamath R (1998) A method to score micronuclei in vivo using cytochalasin B-induced cytokinesis block. Mutat Res 401(1-2):33-37

Uma Devi P, Ganasoundari A, Rao BS, Srinivasan KK (1999) In vivo radioprotection by ocimum flavonoids: survival of mice. Radiat Res 151(1):74-78

Upadhyay AK, Chacko AR, Gandhimathi A, Ghosh P, Harini K, Joseph AP, Joshi AG, Karpe SD, Kaushik S, Kuravadi N, Lingu CS, Mahita J, Malarini R, Malhotra S, Malini M, Mathew OK, Mutt E, Naika M, Nitish S, Pasha SN, Raghavender US, Rajamani A, Shilpa S, Shingate PN, Singh HR, Sukhwal A, Sunitha MS, Sumathi M, Ramaswamy S, Gowda M, Sowdhamini R (2015) Genome sequencing of herb Tulsi (Ocimum tenuiflorum) unravels key genes behind its strong medicinal properties. BMC Plant Biol 15:212

Veerapur VP, Prabhakar KR, Parihar VK, Kandadi MR, Ramakrishana S, Mishra B, Satish Rao BS, Srinivasan KK, Priyadarsini Kl, Unnikrishnan MK (2009) Ficus racemosa stem bark extract: a potent antioxidant and a probable natural radioprotector. Evid Based Complement Alternat Med 6(3):317-324

Verma SP, Tripathi VC, Das P (2014) Asparagus racemosus leaf extract inhibits growth of UOK 146 renal cell carcinoma cell line: simultaneous oncogenic PRCCTFE3 fusion transcript inhibition and apoptosis independent cell death. Asian Pac J Cancer Prev 15(5):1937-1941

\section{Publisher's Note}

Springer Nature remains neutral with regard to jurisdictional claims in published maps and institutional affiliations.

\section{Submit your manuscript to a SpringerOpen ${ }^{\circ}$ journal and benefit from:}

- Convenient online submission

- Rigorous peer review

- Open access: articles freely available online

- High visibility within the field

- Retaining the copyright to your article

Submit your next manuscript at $\gg$ springeropen.com 